DOI 10.4467/2543733XSSB.16.006.6248

PETR PROKS̆

Akademia Nauk Republiki Czeskiej

\title{
„MITTELEUROPA - ZWISCHENEUROPA”. NIEMIECKIE KONCEPCJE EUROPY ŚRODKOWEJ W CZASIE WIELKIEJ WOJNY W LATACH 1914-1918
}

Słowa kluczowe: Mitteleuropa, polityka zagraniczna Niemiec, niemiecka koncepcja Europy Środkowej, Friedrich Naumann

W okresie dynamicznego rozwoju w XIX wieku w Europie Środkowej wyodrębniło się kilka narodów, których nacjonalizm stał się najważniejszą zasadą życia politycznego, kulturalnego i społecznego ${ }^{1}$. Najwyraźniej uwidaczniały się zwłaszcza dążenia Niemiec do całkowitego opanowania tego obszaru. Zgodnie z ówczesnymi poglądami przeważającymi wśród zwolenników „wielkoniemieckiego” rozwiązania przyszłości Europy Środkowej, walka o „mocarstwowa pozycję jednolitej Rzeszy Niemieckiej na świecie” oznaczała przede wszystkim kampanię przeciwko Słowianom, ponieważ stanowili oni większość wśród narodów wchodzących w skład monarchii habsburskiej, dla której zacieśnienie związku z Niemcami było warunkiem sine qua non jej przetrwania ${ }^{2}$.

Jednak kręgi rządzące w Berlinie coraz bardziej wątpiły, czy utrzymywanie przy życiu upadającej monarchii habsburskiej ma jeszcze w ogóle jakiś sens. Zadawano sobie pytanie, czy lepszym rozwiązaniem nie byłoby raczej przyłączenie Przedlitawii, w tym także krajów czeskich, bezpośrednio do Niemiec ${ }^{3}$. Ambasador Niemiec w Wiedniu, Heinrich von Tschirschky, w prywatnym i poufnym liście do niemieckiego ministra spraw zagranicznych Gottlieba von Jagowa 22 maja 1914 pisał, iż często zastanawia się, czy rzeczywiście opłaca

${ }^{1}$ Robert J. W. Evan s, Confession and Nation in Early Modern Central Europe, Central Europe, Vol. 9, 2011, No. 1, s. 2-17; Jiří Ko ř al k a, Češi v habsburské řiši a v Evropě 1815-1914. Sociálněhistorické souvislosti vytváreni novodobého národa a národnostni otázky v českých zemích, Praha 1996; Jan Kř e n, Dvě stoleti středni Evropy, Praha 2005; Ernest A. Ge 11 n e r, Nacionalismus, Brno 2003; Benedict A n d e r s o n, Představy společenství. Úvahy o pưvodu a šíření nacionalismu, Praha 2008; Miroslav H ro c h, Národy nejsou dílem náhody. Př́činy a předpoklady utvářeni moderních evropských národi̊, Praha 2009.

${ }^{2} \mathrm{Jrg}$ Kirch hoff, Die Deutschen in der Österreichisch-Ungarischen Monarchie. Verhältnis zum Staat, zur Deutschen Nation und ihr Kollektives Selbsverständnis (1866/67-1918), Berlin 2001, s. 186.

${ }^{3}$ Hans-Christof Kra u s, Mitteleuropa zwischen Idee und Wirklichkeit. Zur Entwicklung des Mitteleuropa-Gedankes 1815-1945, Prague Papers on the History of International Relations, 2011/1, s. 55-58. 
się jeszcze tak mocno związać Niemcy z pękającym w szwach organizmem państwowym. I nadal wykonywać mozolną pracę, aby uzyskać rekompensatę w postaci korzyści polegających na sojuszu z tą środkowoeuropejską potęgą. Bez wspomnianego aliansu polityka Berlina musi bowiem nieuchronnie zmierzać do podziału monarchii habsburskiej, o ile otrzyma wolną rękę (carte blanche) od Anglii, oraz do trwałego przyłączenia niemieckich terenów naddunajskiej monarchii do Niemiec. Owoce muszą jednak dojrzeć, a czas pokaże, czy jeszcze komuś uda się ponownie trwale połączyć siły odśrodkowe poszczególnych krajów monarchii habsburskiej. Niepowodzenie tej próby z pewnością jeszcze bardziej przyspieszy jej rozkład i do tego musi się dostosować także polityka Niemiec ${ }^{4}$.

\section{Wielkoniemiecka koncepcja Europy Środkowej}

Przełomem w rozwoju Europy Środkowej stała się I wojna światowa. Niemcy uzasadniały rozpętanie wojny również jako konieczność dla przetrwania Austro-Węgier. Niemiecki minister spraw zagranicznych Gottlieb von Jagow w prywatnym liście do niemieckiego ambasadora w Londynie Karola Lichnowskiego 18 lipca 1914 wykluczył pełny sukces Niemiec w rywalizacji z Anglią. Stale słabnące znaczenie i spadający prestiż monarchii, potęgowane przez obecny kryzys bałkański, sprawiały, że wartość sojuszu z monarchią była dla Niemiec coraz mniejsza, które mimo to nie mogły pozwolić na upadek Austro-Węgier. W konsekwencji wojnę z Serbią traktowano jako ostatnią możliwość ,,politycznej rehabilitacji” monarchii habsburskiej. W innym przypadku dojdzie do przyspieszenia procesu jej wewnętrznego rozpadu i na zawsze utraci ona pozycję mocarstwową na Bałkanach, gdzie absolutną przewagę zdobędzie Rosja, którą należy oddzielić od pozostałych sojuszników Ententy, ponieważ ani Francja, ani Anglia nie chcą wojny. Należy także doprowadzić do tego, by konflikt pomiędzy Austro-Węgrami i Serbią przybrał charakter lokalny. Z kolei Rosja nie życzy sobie wojny z Niemcami, które nie mogą monarchii habsburskiej pozostawić samej sobie, jeśli zamierza walczyć, ponieważ w przeciwnym razie zostanie rozbita przez Rosję i dojdzie do zaburzenia dotychczasowej równowagi między obydwiema grupami mocarstw, Trójprzymierzem i Ententą ${ }^{5}$.

Wkrótce po wybuchu I wojny światowej, 9 września 1914 kanclerz Rzeszy Theobald von Bethmann-Hollweg przedłożył dokument pod nazwą ,,Vorläufige Aufzeichnung über die Richtlinien unserer Politik beim Friedensschluß” (,Dyrektywy wstepne dla naszej polityki podczas zawierania pokoju”), zazwyczaj określany jako „Das allgemeine Ziel des Kriges" (memoriał o niemieckich celach wojennych), w którym jest mowa o tym, że:

Rzesza Niemiecka musi być zabezpieczona na zachodzie i wschodzie na jak najdłuższy czas. W tym celu należy na tyle osłabić Francję, aby nie mogła się ponownie odrodzić jako mocarstwo, zepchnąć Rosję na wschód od niemieckiej granicy i przełamać jej rządy nad nierosyjskimi narodami wasalskimi. W konsekwencji:

\footnotetext{
${ }^{4}$ Immanuel Geis s, Deutschland und Österreich-Ungarn beim Kriegsausbruch 1914. Eine machthistorische Analyse, [in:] Michael Gehler - Rainer F. Schmidt - Harm-Heinrich Brandt - Rolf Steininger (eds.), Ungleiche Partner? Österreich und Deutschland in ihrer gegenseitigen Wahrnehmung. Historische Analysen und Vergleiche aus dem 19. und 20. Jahrhundert, Stuttgart 1996, s. 386.

5 Die Deutschen Dokumente zum Kriegsausbruch 1914. Erster Band. Vom Attentat in Sarajevo bis zum Eintreffen der serbischen Antwortnote in Berlin, Berlin 1922, dok. č. 72, s. 99-101.
} 
1. Francja musi oddać tereny na zachód od Wogezów i umożliwić zburzenie swoich umocnień oraz zajęcie pasa nadbrzeżnego od Dunkierki do Bolonii. Konieczne jest zdobycie zagłębia Briey o bogatych złożach rudy żelaznej, ponieważ jest ono ważne dla przemysłu niemieckiego. Odszkodowania wojenne muszą być tak wysokie, aby Francja nie mogła w następnych 15-20 latach przeznaczać należytych środków na zbrojenia. Jednocześnie zostanie z nią zawarta umowa handlowa, powodująca jej gospodarczą zależność od Niemiec, dzięki czemu Niemcy będą miały gdzie eksportować swoje towary, i w rezultacie wyprą z Francji angielskich konkurentów.

2. Belgia musi oddać Prusom swoje regiony nadgraniczne, Liège i Verviers, i stać się państwem wasalskim oraz gospodarczą prowincją Niemiec, które zajmą ważne pod względem wojskowym porty oraz wybrzeże morskie.

3. Luksemburg zostanie poszerzony o część terytorium belgijskiego i przekształci się w państwo związkowe Niemiec.

4. Niezbędne jest zawarcie wspólnych umów celnych i utworzenie środkowoeuropejskiej unii gospodarczej, w skład której weszłaby Francja, Belgia, Holandia, Dania, Austro-Węgry, Polska, Włochy, Szwecja i Norwegia, co zapewniłoby Niemcom hegemonię gospodarczą w Europie Środkowej.

5. Kwestie korzyści kolonialnych, przede wszystkim utworzenie jednolitego imperium kolonialnego w Afryce Środkowej i roszczenia względem Rosji, zostaną rozpatrzone później.

6. Holandia miałaby być ściśle zależna od Niemiec, które będą mieć prawo do zajęcia Antwerpii i ujścia rzeki Skaldy ${ }^{6}$.

Jednocześnie Berlin miał wielkie plany wobec „Wschodu”. Prezydent regencji we Frankfurcie nad Odrą i przewodniczący Związku Wszechniemieckiego „Gesellschaft zur Förderung der Inneren Kolonisation” (Towarzystwo Popierania Kolonizacji Wewnętrznej) Friedrich von Schwerin opracował 25 marca 1915 dla kanclerza Rzeszy memorandum dotyczące wykorzystania wojny do zasiedlenia nowych terenów i powiększenia terytorium Niemiec:

1. W ramach niemieckiego programu oskrzydlenia Rosji Niemcy muszą poszerzyć swoją strefę wpływów na terenach wschodnich. Jako środek do osiągnięcia tego celu może posłużyć „,polskie państwo buforowe” pod niemiecką hegemonią, częściowa aneksja krajów bałtyckich i oddzielenie polskich obszarów granicznych pasem wytyczonym wzdłuż linii rzek Biebrza - Narew - Warta.

2. Zgodnie z tym będzie przebiegać zasiedlanie zdobytych terenów kolonizatorami niemieckimi po spełnieniu następujących warunków: a) opróżnienie tych obszarów z ludności polskiej, b) sprowadzenie niemieckich osadników z Niemiec i Rosji, następnie germanizacja nowo zasiedlonych terenów w Nowych Prusach i krajach bałtyckich, c) oddzielenie zgermanizowanym pasem granicznym Polaków z Prus od pozostałych Po-

\footnotetext{
${ }^{6}$ Německý imperialismus proti ČSR (1918-1939), Praha 1962, dok. č. 1. s. 33-34. Podrobněji viz: Zdeněk J in d r a, Rozpracováni „Středoevropského programu” Bethmanna-Hollwega ve vládnich resortech v prvním válečném roce 1914/15, [in:] Studie z obecných dějin. Sborník prací k sedmdesátým narozeninám prof. dr. Jaroslava Charváta, Praha 1975, s. 141-167; Zdeněk J in d ra, K otázce pronikání némeckého imperialismu na jihovýchod v obdobi pred rokem 1918. Acta Universitatis Carolinae, 1961. Philosophica et Historica, 2, Praha 1961, s. 1-41; Petr Prokš, Projekt „německé” Mitteluropy ve válečných cílech Německa a Rakousko-Uherska (1914-1916), Slovanský přehled, 2002, č. 4, s. 473-498; Petr Prok š, Koncepce „německé” Mitteleuropy ve válečné politice Německa a Rakousko-Uherska (1916-1918), Slovanský přehled, 2003, č. 1, s. 19-42.
} 
laków i ich asymilacja, d) wypłacenie przez polskie państwo buforowe odszkodowań wysiedlonym polskim rolnikom.

3. Zasiedlenie nowo zdobytych obszarów na wschodzie, obok korzyści politycznych, strategicznych i gospodarczych, ma się także przyczynić do zmniejszenia problemów społecznych w samych Niemczech, które jednocześnie poszerzą swoją „bazę” kontynentalną, osiągając pozycję mocarstwową na świecie ${ }^{7}$.

Kanclerz Rzeszy Theobald von Bethmann-Hollweg latem 1915 roku rozważał dwie możliwości rozwiązania kwestii polskiej: 1) Utworzenie autonomicznego Królestwa Polskiego, które musi być w pewnej formie związane z Niemcami lub Austro-Węgrami, 2) Podział Polski w taki sposób, że większa jej część przypadnie Austro-Węgrom, a mniejsza część Niemcom ${ }^{8}$.

Ambicje mocarstwowe Niemiec miały także wyraźne przyczyny gospodarcze. Przedstawiciele sześciu niemieckich zrzeszeń gospodarczych - Bund der Landwirte; Deutscher Bauernbund; Christlichen Deutschen Bauernvereine; Centralverband Deutscher Industrieller; Bund der Industriellen; Reichsdeutscher Mittelstandsverband - przedłożyli 20 maja 1915 kanclerzowi Rzeszy Theobaldowi von Bethmann-Hollwegowi memorandum zawierające ich własne następujące wizje celów wojennych Niemiec:

I. Gtówne cele. Zabezpieczenie niemieckich granic na Zachodzie oraz Wschodzie i poszerzenie panowania na morzach w świecie, zwiększenie siły politycznej, wojskowej, morskiej i ekonomicznej Niemiec, jako mocarstwa kolonialnego, na arenie międzynarodowej.

II. Zachód. 1) Dla zagwarantowania przewagi na morzach oraz odpowiedniej pozycji wojskowej i gospodarczej względem Anglii konieczne jest podporządkowanie Niemcom ważnych części terytorium Belgii pod względem ekonomicznym, wojskowym i transportowym. 2) Z tych samych przyczyn należy doprowadzić do opanowania wybrzeża atlantyckiego Francji, z prawem do wyłącznego korzystania z portów francuskich wokół kanału La Manche, ze względów wojskowo-strategicznych trzeba zająć twierdzę Verdun i Belfort oraz znajdujące się między nimi zachodnie zbocza Wogezów, przyłączyć zagłębie Briey ze złożami rudy żelaznej oraz zagłębie węglowe Nord i Pas de Calais.

III. Wschód. 1) Opanowanie obszarów rolniczych imperium carów w celu zwiększenia produkcji spożywczej i zagwarantowania żywności dla Niemiec. 2) Przyłączenie krajów nadbałtyckich, co poprawi zdolności obronne granic niemieckich w Prusach Wschodnich oraz bezpieczeństwo Prus Zachodnich i Śląska9.

Z kolei stanowisko przedsiębiorców całościowo przedstawił 31 lipca 1915 przemysłowiec Gustav Krupp w memorandum, które opierało się na założeniu, że po zwycięstwie w wojnie należy wykluczyć możliwość konferencji pokojowej, ponieważ Niemcy muszą swym przeciwnikom podyktować swój własny pokój, mający się skoncentrować na trzech głównych celach: 1) Wszyscy Niemcy, którzy są rdzeniem Europy, muszą się jak najsilniej zjednoczyć, aby Europie przewodziła kultura niemiecka. 2) Wykorzystując czynniki polityczne i wojskowe, zapewnić, aby Niemcy w nieodległej przyszłości już nie mogły

\footnotetext{
${ }^{7}$ Immanuel G e is s, Der polnische Grenzstreifen 1914-1918. Ein Beitrag zur deutschen Kriegszielpolitik im Ersten Weltkrieg, Lübeck und Hamburg 1960, s. 72-86.

${ }^{8}$ Jan Žu u an ič, Die polnische Frage in der Politik der Mittelmächte am Beginn des Ersten Weltkriegs, Prague Papers on History of International Relations. Part II, 1998, s. 300.

${ }^{9}$ Deutsch-sowjetische Beziehungen von den Verhandlungen in Brest-Litowsk bis zum Abschluß des Rapallovertrages. Band I. 1917-1918, Berlin 1967, Anhang, dok. č. 1, s. 839-844.
} 
zostać oskrzydlone i nie były uciskane. 3) W sposób zasadniczy rozszerzyć niemiecką działalność gospodarczą w Europie, a także w regionach nadmorskich. Do zrealizowania tego zamiaru konieczne jest spełnienie następujących warunków:

1. Nawiązanie trwałych relacji gospodarczo-politycznych z państwami Europy Środkowej, zwłaszcza z Austro-Węgrami, oraz Holandią, Szwajcarią, Danią, Norwegią i Szwecją, i umożliwienie Niemcom z carskiej Rosji przyłączenia do Niemiec, przy czym w Austro-Węgrzech należy zagwarantować decydujący głos Niemcom.

2. Dla zapewnienia bezpieczeństwa Niemiec przesunięcie niemieckich granic na zachód od Wogezów, na linię rzek Mozeli i Mozy, co pozbawi jednocześnie Francję złóż rud żelaza i węgla. Stąd też Francja ani pod względem gospodarczym, ani politycznym już nie będzie mocarstwem światowym oraz nie będzie stanowić zagrożenia dla Niemiec. Opanowanie Belgii pod względem wojskowym, aby już nie mogła się odrodzić jako samodzielne i neutralne państwo, i północnego wybrzeża Francji, co zapewni ochronę przed atakiem ze strony Anglii, z którą będzie możliwe zachowanie przyjaznych stosunków jedynie wówczas, kiedy Niemcy będą zdolne w każdej chwili jej zaszkodzić, ponieważ jedynie za pomocą środków agresywnych, a nie poprzez łagodne postępowanie uda się zmusić Anglię do odpowiedniego zachowania wobec Niemców. Utworzenie na wschodzie samodzielnej Polski jako państwa buforowego, którego pierwotne tereny nadal pozostaną w posiadaniu Prus, z wyłącznie niemieckim obszarem przygranicznym.

3. Unia celna z Holandią, Austro-Węgrami, Szwajcarią, państwami północnymi i bałkańskimi otworzy nowe możliwości działalności gospodarczej Niemiec, które muszą zadbać o rozwój przemysłu oraz zaplecza rolniczego dla narodu niemieckiego. $Z$ tego powodu należy zdobyć rozległe obszary, na których mogliby się osiedlać Niemcy, zwłaszcza na wschodzie. Obce narody zamieszkujące tereny przylegające i przywłaszczone nie mogą mieć praw wyborczych do Sejmu Rzeszy, a ich liczba zostanie zmniejszona poprzez opanowanie tych terytoriów oraz zniemczenie tamtejszej ludności. Sprawa Alzacji i Lotaryngii zostanie raz na zawsze rozwiązana przez podział tego obszaru pomiędzy Prusy, Bawarię, Wirtembergię i Badenię. W krajach zamorskich wyraźnym celem jest przywrócenie pierwotnych niemieckich posiadłości oraz zajęcie terenów należących dotychczas do Holandii, utworzenie dużego jednolitego imperium kolonialnego w środkowej, południowo-zachodniej i wschodniej Afryce, i uzyskanie punktu oparcia na Morzu Śródziemnym jako mostu do Afryki. Ewentualnie przejęcie, na koszt reparacji wojennych, kolonii francuskich, przede wszystkim Nowej Kaledonii.

Poprzednie propozycje są zatem podstawą do ustalenia warunków, na jakich Niemcy skłonne są zawrzeć pokój: 1) Rezygnacja z konferencji pokojowej. 2) Utworzenie zasad nowych i korzystnych dla Niemiec stosunków handlowo-politycznych. 3) Przyłączenie do Niemiec należących do wroga terytoriów rolniczych i zasiedlenie ich niemieckimi rolnikami, ale bez praw danego kraju do przedstawicielstwa narodowego. 4) Utworzenie wyłącznie niemieckiego pasa granicznego pomiędzy starymi Prusami i nową Polską. 5) Reparacje wojenne w postaci majątku gruntowego, kopalnianego i przemysłowego, który Niemcy uzyskają w wyniku wywłaszczenia ludności autochtonicznej. 6) Nowe uregulowanie stosunków politycznych w Alzacji i Lotaryngii. 7) Utworzenie niemieckiego imperium kolonialnego w Afryce ${ }^{10}$.

${ }^{10}$ Německý imperialismus proti ČSR (1918-1939), Praha 1962, dok. č. 3, s. 37-41. 
$\mathrm{Na}$ przeszkodzie niemieckim planom zmierzającym do opanowania środkowej i wschodniej Europy stała głównie Rosja. Z tej racji po klęsce armii rosyjskiej na froncie wschodnim w maju 1915 roku i w miarę jak wojska państw centralnych przesuwały się na wschód, zajmując ziemie zaboru rosyjskiego pierwotnego Królestwa Polskiego - Polski Kongresowej lub też w skrócie Kongresówki - aktualna okazała się przede wszystkim sprawa przyszłości Polski i jednocześnie habsburskiego związku państw, wraz z perspektywą ewentualnej przebudowy Austro-Węgier w państwo trialistyczne. Na posiedzeniu Rady Ministrów dla zarządu wspólnych spraw Austro-Węgier 6 października 1915 w Wiedniu minister spraw zagranicznych István Burián rozważał możliwość przyłączenia Polski do monarchii habsburskiej, obawiał się jednak, że w przyszłości Rosja zażąda zwrotu Kongresówki, co mogłoby utrudnić negocjacje pokojowe. Równocześnie spory wokół Polski niosły w sobie niebezpieczeństwo w postaci osłabienia związków sojuszniczych z Niemcami, mającymi wielkie plany odnośnie do zabezpieczenia Prus Wschodnich i oddzielenia ich od Rosji kosztem terytoriów pierwotnej Polski. Ponadto przyłączenie Kongresówki do imperium naddunajskiego mogło zdecydowanie wzmocnić tendencje do wprowadzenia w życie koncepcji trializmu i tym samym przyspieszyć rozpad porozumienia austro-węgierskiego z 1867 roku, czemu przeciwstawiali się przede wszystkim Węgrzy, a także zwolennicy utrzymania hegemonii niemieckiej w Przedlitawii. Poza tym doszłoby do umocnienia przewagi liczebnej narodów słowiańskich zamieszkujących monarchię habsburską, a w tej sytuacji niemiecko-węgierskie kręgi rządzące z trudem zdołałyby się przeciwstawić ich roszczeniom prawnopaństwowym. Z tego też powodu premier Austrii Karl von Stürgkh i premier Węgier István Tisza brali pod uwagę różnorodne warianty rozwiązania tej kwestii, zwłaszcza utworzenie z Galicji Wschodniej autonomicznej prowincji, przyłączenie Polski do Austrii, natomiast Dalmacji oraz Bośni i Hercegowiny do Węgier. Oczywiście zastanawiali się także nad skutkami tych posunięć dla sytuacji w Czechach i na Morawach oraz możliwego zaostrzenia stosunków pomiędzy Czechami i Niemcami ${ }^{11}$.

Jednakże Berlin nie liczył się zbytnio ze zdaniem swojego ,sojusznika”. 11 sierpnia 1915 roku cesarz Niemiec Wilhelm II oświadczył, że w toczącej się wojnie Niemcy ponoszą wielkie ofiary, aby wyprzeć ,imperium moskiewskie” na Wschód, z oderwaniem zachodnich ziem państwa carów. Kanclerz Niemiec Theobald von Bethmann-Hollweg 19 sierpnia 1915 w Sejmie Rzeszy w Berlinie w jeszcze ostrzejszej formie oznajmił, iż głównym celem wojny jest „Europa wolna od francuskich knowań, moskiewskiej zaborczości i angielskiego nadzoru". Jedynie silna i niepodważalna pozycja Niemiec może Europie zapewnić pokój, przy czym nie może być mowy o prowadzeniu angielskiej polityki „Balance of Power". Niemcy zamierzają bowiem zbudować tak silną pozycję, aby ponownie żadne inne mocarstwo nie mogło prowadzić przeciwko nim polityki oskrzydlającej ${ }^{12}$.

11 Miklós Komjáthy (ed.), Protokolle des Gemeinsamen Ministerrates der Österreichisch-Ungarischen Monarchie (1914-1918), Budapest 1966, dok. č. 13, s. 285-314. Podrobněji o řešení otázky Polska během první světové války viz: Tomáš Z a hra dníč e k, Jak vyhrát cizí válku. Češi, Poláci a Ukrajinci 1914-1918, Praha 2000; Jan Žu p a nič, Rakousko-Uhersko a polská otázka za první světové války, Praha 2006; Piotr Mik i ety ń s ki, Niemiecka droga ku Mitteleuropie. Polityka II Rzeszy wobec Królestwa Polskiego (1914-1916), Kraków 2009; Damian S zy m c za k, Między Habsburgami a Hohenzollernami. Rywalizacja niemiecko-austro-węgierska w okresie I wojny światowej a odbudowa państwa polskiego, Kraków 2009.

12 Fritz F i s c h e r, Griff nach der Weltmacht. Die Kriegszielpolitik des kaiserlichen Deutschland 1914/18, Düsseldorf 1964, s. 244. 
Niebawem podobne podejście zaprezentował Friedrich Naumann w swojej słynnej książce Mitteleuropa, która ukazała się w październiku 1915 roku w Berlinie i miała otwarcie propagować hegemonię Niemiec w Europie oraz rozszerzenie jej na inne części świata. Podstawą niemieckiej „Europy Środkowej” miał być silny związek Niemiec i Austro-Węgier, do którego stopniowo zostałaby przyłączona Belgia, Holandia, Szwajcaria, Francja, Włochy, Hiszpania, Dania, Norwegia, Szwecja, całe Bałkany, Turcja i kraje Środkowego Wschodu, co ustaliłoby hegemonię Niemiec nad Europą, zapewniając im linie komunikacyjne z Azją Mniejszą i umożliwiając utworzenie niemieckiego imperium kolonialnego, które wspólnie z niemiecką „Mitteleuropa” stałoby się przeciwwagą Wielkiej Brytanii, Rosji, Japonii, Chin i Stanów Zjednoczonych. Wspomniana książka odniosła w Niemczech ogromny sukces i doczekała się kilku dalszych wydań. F. Naumann 22 lutego 1916 założył następnie „Arbeitsausschuß für Mitteleuropa” (Komitet Roboczy dla Europy Środkowej), który miał na wielką skalę spopularyzować propozycje zawarte w książce ${ }^{13}$.

\section{Stanowisko Austro-Węgier wobec „niemieckiej” koncepcji Europy Środkowej}

Austro-Węgry musiały już przed wojną stawiać czoła zaostrzającym się problemom wewnętrznym, tzn. politycznym, prawnopaństwowym, narodowościowym, społecznym oraz gospodarczym, w dodatku z powodu sojuszu z żądnymi wojny Niemcami pogłębiała się ich izolacja na arenie międzynarodowej. Brytyjczycy i Francuzi już nie zamierzali udzielać nowych pożyczek Wiedniowi, który wykorzystywał je na dalsze zbrojenia, gdyż upatrywano w tym zwłaszcza umocnienie pozycji Niemiec. $Z$ tego powodu naddunajskie mocarstwo uważało, że jeszcze ściślejsza współpraca $\mathrm{z}$ niemieckim sąsiadem jest dla niego ostatnią deską ratunku. Minister spraw zagranicznych monarchii habsburskiej Leopold von Berchtold 28 lipca 1913 uskarżał się następcy tronu arcyksięciu Franciszkowi Ferdynadowi d'Este, że z powodu sojuszu z Niemcami, Brytyjczycy i Francuzi zamknęli swój rynek pieniężny dla Austro-Węgier, które tym samym zmierzają ku katastrofie finansowej. Zatem Niemcy muszą dopomóc Austro-Węgrom w odgrywaniu bardziej samodzielnej roli w polityce zagranicznej, ponieważ stawką są żywotne interesy monarchii habsburskiej. Jednak Wiedeń nie chciał i nawet chyba nie mógł się uwolnić z dławiącego uścisku Berlina z obawy, że ostatecznie znajdzie się w izolacji, bez sojuszników i zostanie wydany na pastwę silnej Rosji oraz jej słowiańskich zwolenników zarówno w mocarstwie naddunajskim, jak i na Bałkanach ${ }^{14}$.

Później wojna tylko wzmocniła te wątpliwości. Gdy latem 1915 roku na froncie wschodnim nastąpił zwrot na korzyść mocarstw centralnych, Wiedeń i Budapeszt zaczęły

${ }^{13}$ Friedrich N a u m a nn, Mitteleuropa, Berlin 1915; Jörg Vill a in, Zur Genesis der Mitteleuropakonzeption Friedrich Naumanns bis zum Jahre 1915, Jahrbuch für Geschichte, 15, 1977, s. 207-215; Jiří K o ř a $1 \mathrm{k}$ a, Mitteleuropa Friedricha Naumanna jako plán německé hegemonie v Evropě za první světové války, Dějiny a současnost, XXV, 2003, č. 1, s. 12-16; Václav Ch y s ký, Po stopách konceptů středni Evropy 19. a počátku 20. stoleti se zaměřením na ,Mitteleuropu” Friedricha Naumanna, Střední Evropa. Revue pro středoevropskou politiku a kulturu, 136/2012, s. 116-163.

${ }^{14}$ Gary W. S h a n a fe lt, The Secret Enemy: Austria-Hungary and the German Alliance, 1914-1918, New York 1985, s. 17. 
się obawiać wzrostu ambicji mocarstwowych Berlina w Europie Środkowej. Ambasador Austro-Węgier w Berlinie Gottfried zu Hohenlohe-Schillingsfürst w wiadomości przesłanej do Wiednia 23 czerwca 1915, dotyczącej niemieckiego projektu utworzenia unii celnej Niemiec i Austro-Węgier, stwierdził, że zgodnie ze stanowiskiem Berlina wspomniana unia pod względem politycznym umocni związek obu mocarstw centralnych oraz zwiększy siłę nabywczą ich ludności i jednocześnie poszerzy rynek wewnętrzny, zwiększy siłę eksportu, poprawi międzynarodowy bilans płatniczy i umocni walutę Austro-Węgier. Jednak z drugiej strony istnieją obawy, że ich gospodarka zostanie opanowana przez niemiecki kapita $1^{15}$. Premier Węgier István Tisza w liście do austro-węgierskiego ministra spraw zagranicznych Istvána Buriána 16 lipca 1915 nawet zdystansował się wobec planów Berlina, stwierdzając, że nie chodzi o utworzenie związku środkowoeuropejskiego, ale przede wszystkim o stworzenie czegoś w rodzaju „niemieckiego związku pobocznego" w celu ekonomicznego i politycznego podporządkowania monarchii habsburskiej Niemcom, stąd też istnieje zagrożenie pogłębienia się zależności gospodarczej od Niemiec i w konsekwencji upadku politycznego prestiżu monarchii naddunajskiej ${ }^{16}$.

Wiedeń przede wszystkim nie chciał pozwolić na to, aby został przez Berlin pominięty podczas dzielenia ziem zaboru rosyjskiego. $\mathrm{W}$ trakcie rozmowy z niemieckim kanclerzem Theobaldem von Bethmann-Hollwegiem 13 sierpnia 1915 w Berlinie austro-węgierski minister spraw zagranicznych István Burián domagał się utworzenia $\mathrm{z}$ dawnego zaboru rosyjskiego - czyli Kongresówki - wraz z Galicją i obszarami rusińskimi, Królestwa Polskiego i przyłączenia go do „Cesarstwa Austriackiego” jako obszaru autonomicznego z własnym sejmem krajowym i finansami w postaci jakiegoś subdualizmu w Przedlitawii, przy czym w ogóle nie chodziło o wprowadzenie „trializmu”, czego tak bardzo obawiali się Niemcy. Bethmann-Hollweg kategorycznie sprzeciwił się, aby Polska w takim kształcie była reprezentowana na Radzie Rzeszy w Wiedniu i utworzeniu większości parlamentarnej Polaków, Czechów i Słoweńców przeciwko Niemcom w Przedlitawii, ponieważ nie chodzi o sprawy wewnętrzne Austrii, ale o kwestię o znaczeniu międzynarodowym, bezpośrednio dotyczącą żywotnych interesów „Rzeszy Niemieckiej”. Dlatego zdecydowanie nie zgadzał się z takim rozwiązaniem przyszłości Polski, ponieważ nie może dojść do pogorszenia pozycji gospodarczej Niemiec wobec Rosji, która nadal będzie mieć w swym posiadaniu ponad połowę dawnej Polski i w ogóle nie wchodzi w grę przesiedlenie Polaków i Żydów do Niemiec. Burián bowiem, w zamian za zgodę Niemiec na przyłączenie Królestwa Kongresowego do monarchii habsburskiej, zaproponował z kolei przyłączenie Kurlandii i Litwy do Niemiec ${ }^{17}$.

Jednak Berlin nie chciał utracić pozycji dominującej wobec Wiednia. Kanclerz Theobald von Bethmann-Hollweg ostro przypomniał austro-węgierskiemu ministrowi spraw

15 Willibald Gutsche unter Mitarbeit von Baldur Kaulisch (eds.), Herrschaftsmethoden des deutschen Imperialismus 1897/98 bis 1917. Dokumente zur innen- und außenpolitischen Strategie und Taktik der herrschenden Klassen des deutschen Reiches, Berlin 1977, dok. č. 125, s. 231-232.

${ }^{16}$ Willibald Gutsche unter Mitarbeit von Baldur Kaulisch (eds.), Herrschaftsmethoden des deutschen Imperialismus 1897/98 bis 1917. Dokumente zur innen- und außenpolitischen Strategie und Taktik der herrschenden Klassen des deutschen Reiches..., dok. č. 128, s. 235.

${ }_{17}$ Willibald Gutsche unter Mitarbeit von Baldur Kaulisch (eds.), Herrschaftsmethoden des deutschen Imperialismus 1897/98 bis 1917. Dokumente zur innen- und außenpolitischen Strategie und Taktik der herrschenden Klassen des deutschen Reiches..., dok. č. 129, s. 236-237. 
zagranicznych Istvánowi Buriánowi podczas jego wizyty w Berlinie 10-11 listopada 1915, że sojusz Niemiec i Austro-Węgier od 1879 roku opiera się na hegemonii Węgrów na Węgrzech i Niemców w Austrii. O ile Węgrzy nadal utrzymają dotychczasową pozycję, to wpływ Niemców w drugiej połowie Rzeszy będzie nieustannie osłabiany, i w ten sposób zostanie zagrożona kontynuacja i spójność aliansu, który jest istotą życia lub śmierci Niemiec, dążących do odzyskania swojej dawnej należnej pozycji i niedopuszczenia do przyszłej ,stowianizacji” Europy Środkowej ${ }^{18}$. Wspólna walka obu imperiów przeciwko pozostałym mocarstwom ściśle związała losy Austro-Węgier i Niemiec. Dlatego należy pogłębić wzajemne relacje także w przyszłości i mocno połączyć ze sobą obydwa mocarstwa przeciwko wspólnym wrogom, czyniąc z tego sojuszu stały czynnik polityki międzynarodowej w formie umownego związku w sensie politycznym, gospodarczym i wojskowym. Burián podkreślił, że w tej wojnie muszą ulec poprawie przede wszystkim stosunki wojskowe między Niemcami i Austro-Węgrami, ponieważ w innym przypadku monarchia habsburska nie może, ze względu na słabość swoich finansów, osiągać takich samych wyników jak Rzesza Niemiecka. Natomiast Bethmann-Hollweg przypomniał, że zawarcie sojuszu w 1879 roku opierało się na idei Andrássyego o utrzymaniu hegemonii Węgrów na Węgrzech i Niemców w Austrii. Podczas gdy przewaga Węgrów na Węgrzech stale się wzmacnia, to w Austrii odwrotnie, żywioł niemiecki jest nieustannie osłabiany. Przedłużenie i umocnienie wzajemnego sojuszu jest dla Niemiec sprawą żywotną, ponieważ chodzi o przywrócenie należytej pozycji elementu niemieckiego i powstrzymanie postępującej „słowianizacji” Austrii. Ewentualne przyłączenie Polski do monarchii habsburskiej będzie bowiem oznaczać zwiększenie liczby zamieszkujących ją Słowian o kolejnych 12 milionów. Burián najpierw odrzucił pogląd, że „niemieckości” w Austrii zagraża niebezpieczeństwo ze strony zjednoczonych Słowian, ponieważ są nawzajem skłóceni, przy czym zwłaszcza Polacy wspierają sojusz z Niemcami. Aczkolwiek przyznał, że zdaje sobie sprawę ze zwiększenia wpływu politycznego elementów „nieniemieckich” bardziej, niż jest to pożądane, zwłaszcza Czechów. Taką politykę należy skorygować, ponieważ właśnie w trakcie wojny przyniosła „opłakane skutki”, jako że obecnie w Czechach panuje nastrój zdenerwowania i zamętu. Po przyłączeniu Polski do monarchii habsburskiej zostaną podjęte specjalne kroki, aby nie została w jakikolwiek sposób zagrożona pozycja Niemców pod względem prawnopaństwowym. Jednakże w ogóle nie może być mowy o wprowadzeniu w życie koncepcji „trializmu”, aczkolwiek Polacy domagają się samodzielności, jaką mają Węgrzy i chcą być zarządzani z Warszawy, a nie z Wiednia. Z drugiej strony Rada Rzeszy nie może się obciążać napływem kolejnych polskich posłów, dlatego z Polski i Galicji zostanie utworzony specjalny kraj koronny z własnym sejmem, co spowoduje usunięcie polskich posłów z Rady Rzeszy. Utworzy się „węższą" Radę Rzeszy, która będzie służyć rozwiązywaniu kwestii wspólnych i do niej austriacka Rada Rzeszy i polski sejm będą wysyłać swoich przedstawicieli, wybieranych tak samo jak członkowie przedlitawskich delegacji. W ten sposób Wiedeń pozostawi w swoich rękach Polaków i wzmocni pozycję żywiołu niemieckiego w Austrii. Bethmann-Hollweg mówił następnie o związku gospodarczym w postaci unii celnej w formie preferencyjnych stawek celnych pomiędzy Niemcami a Austro-Węgrami, a zatem o obniżeniu taryf celnych

${ }_{18}$ Richard W. Ka p p, Bethmann-Hollweg, Austria-Hungary and Mitteleuropa 1914-1915, Austrian History Yearbook, Vol. XIX-XX, Part 1, 1983-1984, s. 215. 
z klauzulą najwyższego uprzywilejowania w stosunku do innych państw, podobnie jak to uczyniła Francja i Anglia wobec swych kolonii lub Stany Zjednoczone wobec Kanady. Ewentualnie w taki sposób można by utworzyć środkowoeuropejski lub europejski związek celny na okres 30 lat. Burián wprawdzie wstępnie i niezobowiązująco wyraził na to zgodę, jednak od razu zwrócił uwagę na trudności o charakterze prawnopaństwowym, dotyczące dziesięcioletnich okresów dla uregulowania spraw gospodarczych pomiędzy Austrią i Węgrami, co pociągnęłoby za sobą konieczność zmiany konstytucji. Dlatego mając na uwadze stosunki gospodarcze zarówno między oboma cesarstwami jak i z innymi państwami, proponował „połączenie, ale bez połączenia” - „Anschluss, aber ohne Anschluss". Następnie Bethmann-Hollweg podczas rokowań na temat sprawy polskiej podkreślił, że po ewentualnym podpisaniu separacyjnego pokoju z Rosją, Niemcy chcą odbudować Polskę jako państwo graniczne i obszar tranzytowy do Rosji oraz jako rynek zbytu dla niemieckich towarów ${ }^{19}$.

Berlin jednocześnie podjął konkretne kroki mające prowadzić do połączenia obu mocarstw. Minister spraw zagranicznych Niemiec Gottlieb von Jagow wysłał 13 listopada 1915 do polityków w Wiedniu znane memorandum (czes. Promemoria) rządu Rzeszy w Berlinie z planem długofalowego i ścisłego sojuszu politycznego, gospodarczego i wojskowego obu centralnych mocarstw w celu utworzenia środkowoeuropejskiego związku celnego pod przewodnictwem Niemiec, który następnie oba mocarstwa centralne przeforsowałyby do umowy pokojowej, ponieważ - jak podkreślił - Niemcy i Austria muszą się nawzajem wspierać w organizacji transportu kolejowego przez Bałkany do Orientu i dążyć do utworzenia bezpośredniego połączenia kolejowego Niemiec, Austro-Węgier i Bułgarii ${ }^{20}$. Po zakończeniu wojny, i ewentualnie po odłączeniu regionów peryferyjnych od Rosji, będą się uwidaczniać narastające sprzeczności między mocarstwami centralnymi a Rosją. Zostanie jednocześnie wzmocniony „element nieniemiecki” (w pierwotnym projekcie wymienia się „Słowiaństwo”) w Austrii, co byłoby sprzeczne z zasadami przymierza i międzynarodowymi interesami obu partnerów. $Z$ tego powodu Niemcy we własnym interesie, jak i również monarchii naddunajskiej z całą mocą domagają się, zgodnie z instynktem samozachowawczym, dalszego wzmocnienia związków sojuszniczych, aby podjęto konkretne działania, które zahamowałyby postępującą „słowianizację" Austrii i zagwarantowałyby elementowi „germańskiemu”, a więc mając na uwadze dobro Austrii jako germańskiej Marchii Wschodniej (germanische Ostmark), odpowiednią pierwszoplanową pozycję ${ }^{21}$.

Jednak Wiedeń nie zamierzał tak łatwo ustąpić pod naciskiem Berlina. Ambasador Austro-Węgier Gottfried zu Hohenlohe-Schillingsfürst 24 listopada 1915 przekazał kanclerzowi Niemiec Theobaldowi von Betmann-Hollwegowi odpowiedź Wiednia na niemieckie memorandum. Wynikało z niej, że Wiedeń jest dobitnie przekonany o ko-

\footnotetext{
19 André Scherer - Jacques Grunewald (eds.), L'Allemagne et les problèmes de la paix. Pendant la première guerre mondiale. Documents extraits des archives de 1'Office allemand des Affaires étrangères. I. Des origines a la déclaration de la guerre sous-marine a outrance (août 1914 - 31 janvier 1917), Paris 1962, dok. č. 167, s. $218-221$.

${ }^{20}$ Willibald Gu t s c he, Serbien in den Mitteleuropaplänen des deutschen Imperialismus am Vorabend des ersten Weltkrieges, Zeitschrift für Geschichtswissenschaft, 1975, Heft 1, s. 45.

${ }^{21}$ Paul R. S w e t, Germany, Austria-Hungary and Mitteleuropa: August 1915 - April 1916, [in:] Hugo Hantsch-Alexander Novotny (eds.), Festschrift für Heinrich Benedikt, Wien 1957, s. 198-199.
} 
rzyściach płynących z zacieśnienia i poszerzenia dotychczasowego sojuszu, niemniej z zachowaniem wzajemnej niezależności. Rozmowy muszą uwzględniać możliwości gospodarcze monarchii habsburskiej i dotyczyć przede wszystkim współpracy wojskowej w trwającej akurat wojnie. Zarazem zbliżenie Austro-Węgier i Niemiec w sferze gospodarczej nie może naruszać wzajemnej suwerenności ani też podejmowanych działań gospodarczych i politycznych. Ewentualne utworzenie unii celnej nie może zatem doprowadzić do pogorszenia sytuacji gospodarczej Austro-Węgier. Ważnym i trudnym zadaniem podczas rokowań pokojowych będzie również przeforsowanie unii celnej w takim kształcie, by zaakceptowały ją państwa nieprzyjacielskie, a jeszcze bardziej państwa neutralne. Przy tym wymogiem jest wyraźna poprawa w rokowaniach pozycji wyjściowej Austro-Węgier wobec Niemiec. Ważne będzie także zgodne stanowisko w sprawie rozwiązania kwestii polskiej, aby zarówno Niemcy, jak i Austro-Węgry zrezygnowały ze swojej części ziem polskich zaboru rosyjskiego przy zapewnieniu interesów gospodarczych obu mocarstw. Niemniej podczas interpretowania zasad sojuszu z 1879 roku odnośnie do zagwarantowania hegemonii Węgrów na Węgrzech i Niemców w Austrii doszło do nieporozumienia. Chodziło przede wszystkim o struktury konstytucyjne monarchii austro-węgierskiej dla wszystkich obywateli obu państw monarchii. Uprzywilejowana pozycja Niemców w Austrii opiera się na ich liczbie i specyficznym znaczeniu. Wprawdzie życie polityczne wielonarodowego państwa może tę pozycję nieznacznie zmieniać, jednak nigdy nie może być zagrożona, ponieważ jest zagwarantowana odpowiednim prawodawstwem, które winno być przestrzegane. Rosnące znaczenie pozostałych narodów jest wynikiem podnoszącego się poziomu ich kultury i nie może już być odtąd umniejszane, ale przeciwnie, musi być przyjmowane z aprobatą. Austrii nie zagraża postępująca „słowianizacja”, ponieważ przeciwstawia się jej siła „niemieckości”. Wymagana dominująca pozycja Niemiec może wynikać jedynie z równowagi stosunków politycznych, którym stworzono realne warunki. Forsowanie ich w sposób odgórny w żaden sposób nie przyniosłoby pozytywnego rezultatu. Jest bowiem rzeczą niemożliwą nadanie Niemcom w Austrii statusu większości, gdyż z drugiej strony Niemcy na Węgrzech mają pozycję podrzędną, tak jak wszystkie pozostałe narody. Jedyną gwarancją niezawodnej sojuszniczej polityki monarchii nie może więc być upatrywanie w niej wyłącznie germańskiej Marchii Wschodniej. Należyta pozycja Niemców w Austrii jest bowiem troską jej wewnętrznej polityki, także w przypadku możliwości przyłączenia ziem polskich zaboru rosyjskiego do Austrii. Niemieccy Austriacy sami nie dostrzegają w tej ewentualności dla siebie żadnego niebezpieczeństwa pod warunkiem, że w Radzie Rzeszy „starej” Austrii nie będzie zasiadać żaden Polak. Majoryzacja za pośrednictwem nowego elementu we wspólnych sprawach zostanie wykluczona poprzez podjęcie właściwych kroków. Polacy nie staną się narzędziem agresywnych antyniemieckich tendencji przeciwko swoim ewentualnym przyszłym współobywatelom. Są Słowianami, tak jak Niemcy i Anglicy są Germanami. Idee wszechsłowiańskości nie są wśród nich żywe, stanowią jedynie wymysł rosyjskich polityków ${ }^{22}$.

${ }^{22}$ André Scherer - Jacques Grunewald (eds.), L'Allemagne et les problèmes de la paix. Pendant la première guerre mondiale. Documents extraits des archives de 1'Office allemand des Affaires étrangères. I. Des origines a la déclaration de la guerre sous-marine a outrance (août 1914 - 31 janvier 1917), Paris 1962, dok. č. 168 , s. 221-223. 
Wiedeń, oprócz nacisku zewnętrznego, odczuwał także presję wewnętrzną ze strony zwolenników ścisłego powiązania monarchii habsburskiej z Niemcami. Berlin bowiem w swoim dążeniu do całkowitego podporządkowania sobie Europy Środkowej znajdował zwolenników o wykrystalizowanych poglądach w samych Austro-Węgrzech. Przede wszystkim wśród wielkoniemieckich nacjonalistów w Przedlitawii, którzy całkowicie utożsamili się z wielkomocarstwowymi planami cesarskich Niemiec. Jednocześnie liczyli oni na przeforsowanie własnych roszczeń mocarstwowych w monarchii habsburskiej w postaci wprowadzenia bezwarunkowej hegemonii niemieckiej w Przedlitawii. Szerokie spektrum tego ugrupowania, począwszy od polityków społecznych aż po ogólnoniemiecko i nacjonalistycznie zorientowane kręgi szlachty, przygotowało w latach 1915-1916 własny plan wprowadzenia specjalnych zasad „konstytucyjnych”, służących zagwarantowaniu Niemcom pozycji większościowej z wykluczeniem przewagi Słowian. Właśnie to środowisko najpierw w 1915 roku wyszło z inicjatywą przekształcenia Austro-Węgier w konfederację czterech autonomicznych państw: 1) Kraje alpejskie - ziemie austriackie, Czechy, Morawy, Śląsk, kraje nadmorskie i Triest; 2) Chorwacja, Slawonia, Bośnia, Hercegowina, Dalmacja i anektowana Serbia; 3) Węgry - Górne i Dolne Węgry, bez Chorwacji i Slawonii; 4) Galicja Wschodnia, Bukowina i rosyjska część Podola. Jednocześnie Galicja Zachodnia zostałaby przyłączona do odrodzonej Polski, utworzonej poprzez połączenie pierwotnego zaboru pruskiego, austriackiego i rosyjskiego byłego Królestwa Polskiego, pod kontrolą Berlina i Wiednia. Zarazem dla „krajów alpejskich” miał powstać wspólny sejm w Wiedniu, ze specjalnym systemem wyborczym, który by zagwarantował przewagę dwóch trzecich głosów Niemców nad Czechami ${ }^{23}$.

Także w tych kręgach w Przedlitawii powstał słynny dokument „Denkschrift aus Deutsch-Österreich” (Memorandum z Niemieckiej Austrii), opublikowany we wrześniu 1915 roku, autorstwa historyka i zwolennika idei wszechniemieckich, nacjonalisty Heinricha Friedjunga, który wyraził głębokie przekonanie, że ostatecznym celem mocarstw centralnych musi być ich rozwój polityczny i gospodarczy, co można osiągnąć jedynie przez ścisłe powiązanie Austro-Węgier i Niemiec, oparte na umowach politycznych, wojskowych i gospodarczych. W sferze politycznej powinno się zawrzeć związek wojskowy na okres dwudziestu pięciu lat, $\mathrm{z}$ udzieleniem wzajemnych gwarancji zachowania integralności terytorialnej obu mocarstw, a po skończeniu wojny wprowadzić „nowy porządek" w Polsce i Belgii oraz na Bałkanach. Każde z obydwu mocarstw miałoby znać treść wszystkich jawnych i tajnych umów swojego sojusznika jeszcze przed ich uchwaleniem. Jednocześnie mocarstwa powinny jak najmocniej połączyć swoje siły wojskowe, nie naruszając przy tym własnej niezależności i jednorodności wewnętrznej. Niemniej zostanie powszechnie uznana nadrzędność organizacji wojskowych i armii Niemiec nad armią Austro-Węgier przy wprowadzaniu wspólnych typów uzbrojenia i zharmonizowaniu aprowizacji, służb wywiadowczych i planów strategicznych, co powinien zapewnić wspólny sztab generalny. Wszelkie formy stosunków wojskowych muszą zostać ustalone w specjalnej umowie wojskowej. W sferze gospodarczej oba mocarstwa centralne miałyby

${ }^{23}$ Mu n in (Karl Iro - německý nacionalistický politik z českých zemí, představitel všeněmecké strany), Österreich nach dem Kriege. Forderungen eines aktiven österreichischen Politikers, Jena 1915; viz Karel Pichlík (ed.), T. G. M a s r r k, Válka a revoluce I. Články - memoranda - přednášky - rozhovory 1914-1916, Praha, Masarykův ústav AV ČR 2005, s. 48, pozn. 4, s. 73-76. 
dążyć do stworzenia unii celnej i handlowej z cłami preferencyjnymi, do której mogłyby się przyłączyć także sąsiednie państwa, z ostatecznym dążeniem do wprowadzenia wspólnego systemu celnego ${ }^{24}$.

Wreszcie wielkoniemieccy nacjonaliści w kwietniu 1916 przedstawili w Wiedniu program pod nazwą , Żądania Niemców z Austrii dotyczace nowego porządku po zakończeniu wojny” - określany jako „Program Wielkanocny”. Chodziło przede wszystkim o wyraźne wzmocnienie roli centralnych organów biurokratycznych Wiednia z rozbiciem tradycyjnych jednostek terytorialnych oraz, i tak już ograniczonej, autonomii krajów koronnych. W oparciu o to miała powstać „niemiecka” Austria, która później zostałaby przyłączona do Niemiec. Jednocześnie historyczne kraje czeskie - Czechy, Morawy i Śląsk miałyby się przekształcić w zwykłe prowincje Austrii, a później Niemiec. Powyższe przemyślane kroki zakładały zanik dotychczasowych krajów historycznych czy też , koronnych" Przedlitawii i przekształcenie ich w jednolite „Cesarstwo Austriackie” pod hegemonią Niemców w następujący sposób: 1) Bukowina, Dalmacja, Galicja i zdobyte w trakcie wojny tereny Polski i Ukrainy otrzymają własny samorząd z lokalnymi parlamentami bez przedstawicielstwa w Radzie Rzeszy w Wiedniu. 2) Czeskie kraje koronne - Czechy, Morawy i Śląsk - zostaną podzielone na wyłącznie niemieckie i mieszane niemiecko-czeskie regiony według klucza narodowościowego bez uwzględniania granic historycznych. 3) Dotychczasowe kraje austriackie pod nazwą „Austria Zachodnia” zachowają swą integralność. 4) Zgodnie $\mathrm{z}$ tym podziałem terytorialnym zostaną rozdzielone mandaty $\mathrm{w}$ zarządzie miejskim i krajowym oraz w Radzie Rzeszy w Wiedniu, co zagwarantuje hegemonię Niemców, a jedynym językiem urzędowym w Przedlitawii stanie się wyłącznie język niemiecki z konsekwentną ,,ochrona" narodowego znaczenia Niemców także we wszystkich krajach Węgier. 5) Bośnia i Hercegowina oraz nowo zdobyte tereny na Bałkanach na długi czas pozostaną pod zarządem wojskowym. 6) Powstanie związek polityczny, wojskowy i gospodarczy z Niemcami, potwierdzony odpowiednimi umowami, zwłaszcza związek ekonomiczny i celny z centralną polityką handlową obu mocarstw. W końcu nastąpi utworzenie jednolitego obszaru gospodarczego w Europie Środkowej z wolną żeglugą w całej dolinie Dunaju - czyli właściwie przyjęcie projektu niemieckiej „,Mitteleuropy”. 7) $\mathrm{W}$ celu zwiększenia swojego znaczenia mocarstwa naddunajskie zapewnią sobie wolną drogę z Adriatyku i wyeliminują wszelki wpływ Włoch ze wschodniego wybrzeża Adriatyku. 8) Będzie funkcjonować wspólna granica imperium naddunajskiego z Bułgarią w rzeczywistości oznaczało to aneksję terytorium Serbii ${ }^{25}$.

Wiedeń, oprócz sprzeciwu wobec nacisku Berlina, coraz aktywniej zajmował się przede wszystkim sprawą przyszłości Polski. W rozmowie z niemieckim kanclerzem Theobaldem von Bethmann-Hollwegiem 18 kwietnia 1916 w Berlinie minister spraw zagranicznych István Burián podkreślił, że kiedy Polska zostanie wyswobodzona spod władzy Rosji, to nie będzie możliwe zachowanie terytorialnego status quo Austro-Węgier, ponieważ albo utracą Galicję, która przypadnie nowej Polsce, albo Królestwo Kongresowe zostanie w jakiś sposób ściśle przyłączone do Austro-Węgier. Problemy monarchii habs-

${ }^{24}$ Paul R. S w e et, Germany, Austria-Hungary and Mitteleuropa: August 1915 - April 1916, [in:] Hugo Hantsch - Alexander Novotny (eds.), Festschrift für Heinrich Benedikt..., s. 184-186.

${ }_{25}$ Sborník dokumentů $k$ vnitřnímu vývoji v českých zemích za 1. světové války 1914-1918. Svazek III Rok 1916, Praha 1995, dok. č. 39, s. 115-124. 
burskiej martwiły również Berlin. $\mathrm{Z}$ tego też powodu kanclerz Theobald von Bethmann-Hollweg 29 września 1916 zwrócił uwagę feldmarszałkowi i szefowi sztabu generalnego Paulowi von Hindenburgowi na niezdolność Austro-Węgier do kontynuowania wojny, co może sprawić, że pierwszym ich krokiem będzie zawarcie pokoju separatystycznego $\mathrm{z}$ wrogami, przed podporządkowaniem się hegemonii Niemiec. Następnie w dokumencie z 10 listopada 1916 uskarżał się, że na Niemczech spoczywa brzemię wzajemnego sojuszu, przy czym wsparcie monarchii habsburskiej nie ma żadnych prawnopaństwowych ani międzynarodowych podstaw, co się może $\mathrm{w}$ wyniku jego natężenia obrócić przeciwko Niemcom. W czasie wojny nie zostały bowiem zerwane stosunki Austro-Węgier z Anglią i Francją, które podczas rozmów pokojowych chętne są zapewnić im korzystniejszą pozycję, jeśli wejdą w spór z Niemcami, co może w przyszłości na stałe wpłynąć na międzynarodową pozycję Niemiec ${ }^{26}$.

\section{Niepowodzenie koncepcji „niemieckiej” Europy Środkowej}

Niemniej trwająca wojna spowodowała zaostrzenie sprzeczności gospodarczych, społecznych, narodowościowych i politycznych w Austro-Węgrzech. Pogłębiające się problemy wewnętrzne swojego „sojusznika” od wiosny 1918 roku wykorzystał Berlin do bezwzględnego nacisku na Wiedeń. Elementem składowym mocarstwowych zamiarów cesarskich Niemiec u schyłku wojny było także dążenie do ostatecznego rozwiązania przeciągających się negocjacji z Austro-Węgrami, dotyczących ukształtowania w przyszłości nowego porządku w Europie Środkowej. Po słynnej aferze z księciem Sykstusem z kwietnia 1918 roku Berlin stanowczo zmusił Wiedeń do bezwarunkowego podporządkowania. Cesarz Austrii Karol oraz minister spraw zagranicznych Austro-Węgier István Burián i cesarz Niemiec Wilhelm II oraz kanclerz Rzeszy Georg von Hertling podpisali 12 maja 1918 w niemieckiej Kwaterze Głównej w belgijskim Spa umowę o współpracy Niemiec i Austro-Węgier, która zakładała: 1) doprowadzenie do zawarcia długofalowego i ścisłego sojuszu politycznego, służącego obronie i bezpieczeństwu obu mocarstw, 2) utworzenie związku wojskowego, 3) stopniowe budowanie unii celnej i gospodarczej, która następnie usunęłaby wszystkie cła między Austro-Węgrami a Niemcami. Ten związek celny i gospodarczy nie miał przybierać żadnego agresywnego charakteru wobec pozostałych państw ani naruszać przyjaznych stosunków handlowych między nimi. Warunkiem spełnienia wyżej wymienionych zasad miałoby być osiągnięcie konsensusu w sprawie polskiej ${ }^{27}$.

Berlin miał przy tym na uwadze trzy główne cele: 1) Zmuszenie monarchii habsburskiej do rezygnacji z ,austro-polskiego” i przyjęcie „germańsko-polskiego” rozwiązania sprawy polskiej, co oznaczało utworzenie z Polski państwa buforowego, pod hegemonią Niemiec, zabezpieczającego przed Rosją. 2) Zupełne wyparcie monarchii naddunajskiej z Bałkanów, aby znalazły się one tym samym pod całkowitą kontrolą Niemiec, jako brama do Orientu, czyli do Azji Mniejszej i na Środkowy Wschód. 3) Uniemożliwienie jakichkolwiek innych stosunków lub nawet pertraktacji Austro-Węgier z Ententą kosztem Niemiec. Berlinowi udało się złamać opór Wiednia, oprócz sprawy Polski, ponieważ

\footnotetext{
${ }^{26}$ Ingeborg Meckling, Die Aussenpolitik des Grafen Czernin, Wien-München 1969, s. 63-64.

${ }_{27}$ Jan O p oč en s ký, Konec monarchie rakousko-uherské, Praha 1928, s. 769-770.
} 
przedstawiciele monarchii habsburskiej obawiali się, że w ten sposób utraciliby Galicję, co mogłoby zapoczątkować reakcję łańcuchową, prowadzącą do nieuchronnego rozpadu całego związku państw. Pamiętając o tym, przystąpili niebawem do negocjacji dotyczących zbliżenia gospodarczego obu mocarstw centralnych z niemieckimi partnerami, które przebiegały od 9 lipca do 10 października 1918 w Salzburgu. Na czele delegacji austro-węgierskiej stał szef wydziału handlowo-politycznego ministerstwa spraw zagranicznych G. Gratz, natomiast na czele niemieckiej - dyrektor wydziału handlowo-politycznego ministerstwa spraw zagranicznych, P. von Koerner. Najpierw strony biorące udział w negocjacjach doszły do porozumienia w następujących sprawach: 1) celem rozmów ma być unia celna, 2) jednolity obszar gospodarczy może powstać dopiero po okresie przejściowym, 3) dlatego na razie nie będą tworzone wspólne organy celne, 4) cła wobec krajów trzecich w przyszłości zostaną ujednolicone, niemniej w okresie przejściowym dotychczasowe różnice będą zachowane, 5) będzie realizowana wspólna polityka handlowa, 6) unia gospodarcza nie będzie mieć charakteru agresywnego. Jednak problemy zasadnicze w rozmowach bardzo szybko zeszły na plan dalszy, skoncentrowano się natomiast na drugorzędnych kwestiach taryf celnych na poszczególne rodzaje towarów, o które negocjatorzy twardo spierali się, stąd też całe rokowania bardzo się przeciągały, bez możliwości osiągnięcia kompromisu. W danej chwili było to na rękę zwłaszcza Wiedniowi, który nie zamierzał do niczego konkretnego zobowiązywać się, ponieważ przy obecnym stosunku sił obu mocarstw musiałby czynić wyraźne ustępstwa, a na to oczywiście nie miał w ogóle ochoty. Ponadto na przebieg posiedzenia coraz większy wpływ miały wydarzenia wojenne, dlatego też obie strony zaczęły sobie coraz dobitniej uświadamiać, że sprawa przyszłości gospodarczej Europy Śodkowej będzie niewątpliwie rozwiązywana na poziomie międzynarodowym. Wskutek tego 9 września 1918 obwieściły, że trwające negocjacje mają charakter przygotowawczy i nie są wiążące. Ostatecznie cała próba spełzła absolutnie na niczym, ponieważ Niemcy i Austro-Węgry, w obliczu nieuchronnie zbliżającej się porażki, zaczęły mieć zupełnie inne problemy ${ }^{28}$.

Zwolennicy wielkoniemieckiego rozwiązania przyszłości Europy Środkowej oczekiwali, iż rozmowy w Salzburgu urzeczywistnią także ich wizje wielkomocarstwowe. „Arbeitsausschuß für Mitteleuropa” (Komitet Roboczy dla Europy Środkowej) F. Naumanna przedłożył 20 lipca 1918 w Berlinie memorandum z żądaniami połączenia Niemiec i Austro-Węgier w sferze politycznej, wojskowej i gospodarczej oraz utworzenia unii celnej, która wzajemnie otworzy większe rynki dla ich przemysłu i umożliwi im ponowne włączenie się w światowy handel. Jednocześnie w ten sposób obydwa mocarstwa zagwarantują hegemonię polityczną Niemców w Przedlitawii oraz zabezpieczą wspólne interesy na wschodzie względem Polski, obszaru nadbałtyckiego, Rosji, Ukrainy i na Bałkanach $^{29}$. Jednak wobec tych propozycji podnosiły się głosy sprzeciwu pochodzące z tych kręgów przedsiębiorców, którzy uważali unię celną w dotychczasowej postaci za zbyt ograniczającą, ponieważ przeforsowanie swych zamiarów wiązali już z o wiele większym obszarem. Dyrektor generalny przedsiębiorstw firmy Krupp, A. Hugenberg, 20 lipca 1918 w imieniu głównych związków gospodarczych przedłożył rządowi Rzeszy memorandum,

${ }^{28}$ Dušan Kováč, Zákulisie a význam salzburských rozhovorov medzi Nemeckom a Rakúsko-Uhorskom $v$ lete 1918, Historický časopis, XXII, 1974, č. 1, s. 34-45.

${ }^{29}$ Německý imperialismus proti ČSR (1918-1939), Praha 1962, dok. č. 4, s. 42-44. 
w którym stwierdzono, że dla niemieckiego handlu zagranicznego, który był po wojnie bardzo zagrożony, Austro-Węgry stanowią zbyt wąskie ramy, dlatego też na nich nie można w przyszłości się opierać. Niemcy muszą pójść o wiele dalej, w kierunku utworzenia związku celnego na całym terenie Europy kontynentalnej. Przede wszystkim muszą się skupić na rozległych obszarach, które jako państwa buforowe udało się oderwać od byłej carskiej Rosji $i^{30}$.

Jednak przegrana armii niemieckiej na froncie zachodnim w sierpniu 1918 zmusiła Berlin do zdecydowanego przewartościowania pierwotnych wygórowanych ambicji mocarstwowych. Ostatni kanclerz cesarskich Niemiec książę Maksymilian von Baden, przedstawiając program swojego rządu 5 października 1918 w Sejmie Rzeszy w Berlinie, objaśniał niemieckie cele wojenne zgodnie ze znanymi czternastoma punktami amerykańskiego prezydenta Thomasa Woodrowa Wilsona, czyli w zasadzie ich niemiecką wykładnię: 1) Niemcy akceptują zawarcie specjalnej umowy pokojowej wykluczającej powstanie porozumień obronnych oraz zaczepnych i gwarantującej jawną dyplomację pod kontrolą opinii publicznej narodów. 2) Niemcy zgadzają się na wolność żeglugi morskiej, zarówno w czasie pokoju, jak i w czasie wojny, aby zamknięcie mórz już nigdy nie stało się narzędziem zagłady narodów. 3) Niemcy chcą mieć takie sama prawa i nie chcą mieć żadnych udogodnień $\mathrm{w}$ handlu $\mathrm{z}$ innymi narodami, ponieważ właśnie podobne przywileje były przyczyną dotychczasowych sporów między narodami. 4) Niemcy nie odrzucają równoprawnego i zrównoważonego rozbrojenia wszystkich krajów, łącznie ze swoimi sąsiadami, na ziemi, morzu i w powietrzu. 5) Sprawy kolonialne należy rozwiązać z punktu widzenia interesów gospodarczych narodów europejskich, przy czym podstawą powinno być dążenie do przywrócenia panowania nad koloniami zgodnie z przedwojennym stanem rzeczy. 6) Wycofanie się z Rosji i wolność dla niej ma dotyczyć jedynie obszarów zamieszkiwanych dawniej przez Rosjan, podczas gdy pozostałe narody i terytoria byłego imperium carskiego, jak na przykład Polacy i Litwini, narody bałtyckie i kaukaskie lub Finlandia i Ukraina, miałyby całkowicie swobodnie decydować o swoim losie, z wykluczeniem terroru demagogicznego lub wojskowego; prawo tych narodów do samostanowienia musi być zagwarantowane przez nadzór międzynarodowy, przy równoczesnym zapewnieniu prawa każdego z regionów, by w przyszłości na przykład mógł ponownie połączyć się z nową Rosją. 7) Niemcy zgadzają się na przywrócenie suwerenności i integralności Belgii. 8) Niemcy nie chcą przywłaszczyć sobie żadnego terytorium Francji i są gotowe przystąpić do rokowań w sprawie Alzacji i Lotaryngii ze swoimi wrogami. Sprzeciwiają się jednak poglądowi prezydenta Wilsona, że przyłączenie Alzacji i Lotaryngii do Niemiec w 1871 roku było aktem bezprawia, ponieważ już o wiele wcześniej właśnie Francja przemocą oderwała od Niemiec Alzację i Lotaryngię, które stały się w ten sposób kością niezgody w Europie. Ich losy nie mogą być zatem rozwiązane na wzór dawnego bezprawia, ale zgodnie z prawem historycznym, gdyż ludność Alzacji i Lotaryngii nie może być podporządkowana ani porządkom wojskowym z ramienia armii niemieckiej, ani też skazana na bezwzględny szowinizm francuski i zgodnie z tym należy zadecydować także o ich przyszłości. 9 i 10) ,Ułożenie stosunków wewnętrznych Austro-Węier $i$ uregulowania z Włochami sa sprawa naszego wiernego sojusznika, którego interesy

${ }^{30}$ Zdeněk Jindra, Pozice a cíle německého kapitálu v Rusku v letech první světové války, Slovanský přehled, 1976, č. 5, s. 365 . 
leża nam na sercu, jak nasze własne”. 11) Takie samo stanowisko dotyczyło Rumunii, Serbii i Czarnogóry. 12) Podobnie Turcję muszą obowiązywać identyczne zasady, jak wszystkie kraje zamieszkane przez różne narody. Przykładem rozwiązania takich problemów narodowościowych jest Szwajcaria, będąca ojczyzną trzech różnych narodowości.

13) Niemcy wyrażają zgodę na powstanie niepodległej Polski, jednak należy mieć na uwadze żywotne interesy sprzymierzonych Austro-Węgier, a także zagwarantowanie praw narodowościowych i religijnych mniejszości w Polsce. 14) Zasady mającego powstać związku narodów dla zapewnienia pokoju muszą obowiązywać także wszystkich dotychczasowych wrogów, planujących po zakończeniu działań wojennych wojnę gospodarczą przeciwko Niemcom, które chcą mieć takie same możliwości rozwijania działalności rynkowej, jak wszystkie wrogie kraje. W innym przypadku propozycje utworzenia podobnego związku są zwykłym frazesem, ponieważ w rzeczywistości, pod względem komercyjnym, będzie on związkiem wrogim, skierowanym przeciwko Niemcom i kontynuacją wojny za pomocą innych środków ${ }^{31}$.

Wprawdzie dawne aspiracje mocarstwowe Niemiec przepadły bezpowrotnie, jednak Berlin nie zamierzał pogodzić się z faktem, że wojna (aczkolwiek przegrana) nie przyniesie mu żadnych korzyści. Zatem skoncentrował swoją uwagę na własnym sąsiedzie i sojuszniku, rozważając „Anszluss”, czyli pozyskanie niektórych części rozpadającej się monarchii habsburskiej, do czego chciał wykorzystać zwłaszcza prądy wszechniemieckie w Przedlitawii. Niemiecki ambasador Botho von Wedel w przesłanej z Wiednia 2 października 1918 wiadomości donosił, że w monarchii naddunajskiej przygotowano grunt pod rozległy ruch irredentystyczny, do którego mogłaby się włączyć wszelka ludność niemiecka. Rada Rzeszy powinna się do tego ruchu odpowiednio przygotować, ponieważ należy dyplomatycznie uspokoić austriackich Niemców, że mają pozostać lojalni. Równocześnie nie byłoby rzeczą wskazaną obcesowo im odmówić. Następnie ambasador Botho von Wedel 11 października 1918 ponownie przekazał do Berlina wiadomość, że rzekome plany dynastii habsburskiej, mające na celu utrzymanie ich monarchii, mogłyby spowodować, że stałaby się ona w przeważającej mierze państwem słowiańskim. Austriaccy Niemcy chcą zapobiec temu niebezpieczeństwu przez przyłączenie do Niemiec tak szybko, jak to tylko będzie możliwe. Ponieważ od tego kroku na razie powstrzymuje ich brak pewności co do stanowiska Niemiec, nalegał na jak najszybszą pozytywną odpowiedź rządu Rzeszy, który powinien uznać prawo austriackich Niemców do samostanowienia i wyrazić gotowość przyjęcia ich do Niemiec. Niemniej żądanie przyłączenia musi nadejść od austriackich Niemców, w innym przypadku Ententa mogłaby to uznać za imperializm niemiecki. Niemcy powinny się też przygotować na niebezpieczeństwo w postaci ucisku ekonomicznego na niemieckich obszarach Czech, co miałoby na celu niedopuszczenie do Anszlussu. Wkrótce, 14 października 1918 niemieckie ministerstwo spraw zagraniczych w Berlinie dało do zrozumienia swojemu ambasadorowi w Wiedniu Botho von Wedelowi, że ewentualną ingerencją wojskową w Czechach zajmują się niemieckie władze wojskowe przy naczelnym dowództwie armii austro-węgierskiej, z którymi na ten temat tymczasem rozmawiali także przedstawiciele Niemiec z krajów czeskich ${ }^{32}$.

\footnotetext{
${ }^{31}$ Max v o n B a de n, Erinnerungen und Dokumente, Berlin und Leipzig 1927, s. 361-365.

${ }^{32}$ Aarthur C. Kogan, Genesis of the Anschluss Problem: Germany and the Germans of the Habsburg Monarchy in the Autumn of 1918, Journal of Central European Affairs, XX, 1960, No. 1, s. 25-26.
} 
Polityczne i wojskowe kierownictwo Niemiec we wrześniu i październiku 1918 rozważało różne możliwości rozwiązania sytuacji w Europie Środkowej. Uwzględniając dotychczasowy rozwój wydarzeń, brano pod uwagę zwłaszcza możliwość reform wewnętrznych lub nawet rozpad Austro-Węgier, a następnie powstanie Czechosłowacji ${ }^{33}$. Jednocześnie uwzględniano następujące opcje: 1) bezwarunkowe uznanie suwerenności państwa czechosłowackiego, 2) uznanie czeskiej autonomii wewnątrz Austrii lub formalnej niepodległości, ale bez pogranicza ziem czeskich, 3) interwencja wojskowa. Interwencję wojskową forsował przede wszystkim przedstawiciel Niemiec przy Najwyższym Dowództwie Armii Austro-Węgierskiej, generał August von Cramon, wraz ze swoimi współpracownikami, zalecając również, aby Niemcy w Czechach bez wiedzy rządu austriackiego w sposób tajny zostali zaopatrzeni w broń i amunicję, ponieważ byliby gorzko rozczarowani, gdyby nie nadeszła pomoc z Niemiec. Generał August von Cramon zaproponował Niemieckiemu Dowództwu Naczelnemu, aby w Prusach, Saksonii i Bawarii przygotowano uzbrojone ,jednostki policyjne", gotowe do wtargnięcia na czeskie pogranicze w przypadku stracia Niemców z Czechami. Stanowisko generała Augusta von Cramona było odzwierciedleniem poglądów Niemieckiego Dowództwa Naczelnego, które starało się zmusić rząd monarchii do bardziej zdecydowanych kroków, ponieważ ze względu na odnoszące zwycięstwa państwa Ententy zachowywał się on rozważniej. Generał Erich Ludendorff przesłał 14 października 1918 do niemieckiego ministra spraw zagranicznych Wilhelma Solfa memorandum, w którym stwierdzał, że już nie uda się zapobiec powstaniu ani państwa czeskiego, ani też jugosłowiańskiego. Z tego powodu zalecał natychmiastowe przyłączenie wszystkich terenów Austrii zamieszkiwanych przez Niemców do Niemiec, jako że nie mogą liczyć na przyjaźń państwa czeskiego i południowosłowiańskiego, tak samo jak na przychylność Polski. Również cesarz Niemiec Wilhelm II 14 października 1918 wysłał do ministra spraw zagranicznych Wilhelma Solfa własne memorandum, mówiące o tym, że Habsburgowie popełnili błąd w polityce wewnętrznej, nie decydując się na sojusz z Niemcami i nie wspierając Germanów przeciwko Słowianom. Obawiając się niemieckiej irredenty, umożliwili tym samym rozwój Czechów i pozostałych Słowian kosztem austriackich Niemców, czyli jedynym wyjściem jest obecnie przyłączenie niemieckiej Austrii do Niemiec. Ich ambasador Botho von Wedel w wiadomości wysłanej 16 października 1918 z Wiednia do kanclerza Rzeszy Maksymiliana von Badena otwarcie wskazał na prawdziwy sens tych rozważań, pisząc, że przyłączenie północnych Czech z bogatymi złożami węgla przyniosłoby duże korzyści dla Niemiec, którym nie można byłoby stawiać zarzutów z powodu tego kroku, ponieważ nie byłby on wymierzony przeciwko Wiedniowi, ale przeciw Czechom ${ }^{34}$.

Jednak Wiedeń także starał się manewrować między presją Berlina a zaostrzającymi się problemami wewnętrznymi związku państw naddunajskich. Cesarz Austrii Karol I wobec narastających kłopotów monarchii habsburskiej 16 października 1918 wydał manifest o przekształceniu Austrii w wielonarodową strukturę federacyjną, gdzie każdy naród na zamieszkiwanym przez siebie terytorium stworzy swój własny system państwowy. Pier-

${ }^{33}$ Eva B roklová, Osud českého národa v německých zámérech (Od roku 1848 do druhé světové války), Spory o dějiny. Sborník kritických textů, IV, 2003, s. 137-147.

34 Jiří K oř alk a, Vznik Československé republiky roku 1918 v oficiální politice Německé řiše, Československý časopis historický, XVI, 1968, č. 6, s. 838-841. 
wotnie brano pod uwagę utworzenie państwa niemiecko-austriackiego, czeskiego, południowosłowiańskiego i ukraińskiego. Zarazem nie wykluczano połączenia polskich ziem w Austrii (zaboru austriackiego) z niepodległym państwem polskim, podczas gdy Triest miał otrzymać specjalną pozycję, ale regulacja ta w żaden sposób nie dotyczyła integralności terytorialnej Węgier ${ }^{35}$.

Niemniej Berlinowi zasadniczo nie podobała się perspektywa narodowo-państwowej „parcelacji” Przedlitawii, a tym samym rozdrobnienia pozycji austriackich (przedlitawskich) Niemców jako potencjalnych sojuszników Niemiec. Niemiecki minister spraw zagranicznych Wilhelm Solf 19 października 1918 wysłał przez specjalnego kuriera prywatny list do ambasadora Botho von Wedela do Wiednia, w którym obszernie uzasadniał, dlaczego daje pierwszeństwo kontynuacji wcześniejszej polityki kanclerza Otto von Bismarcka, dążącego do zachowania i umocnienia monarchii naddunajskiej jako sojusznika w obronie przeciwko niebezpieczeństwu zagrażającemu ze Wschodu. Warunkiem tej polityki było wspieranie hegemonii Niemców w Austrii i Węgrów na Węgrzech. Zwłaszcza hegemonia Niemców w Austrii gwarantowała podtrzymywanie zadowolenia środowisk lojalnych wobec cesarza i umiar w ich żądaniach, zapobiegając w ten sposób nasileniu tendencji irredentystycznych, naruszających stosunki z Niemcami. Rządowi wiedeńskiemu nie udało się uratować tego silnego wsparcia tronu habsburskiego, aby zgodnie z zasadą „divide et impera” stosować politykę wygrywania jednych narodów przeciw drugim. W ten sposób doszło do nasilenia roszczeń Polaków i Czechów kosztem Niemców, co pobudziło irredentę niemiecką, która miała na celu doprowadzenie do stłumienia niezadowolenia Czechów przez Wiedeń. Nieprzemyślana polityka Wiednia - podkreślał - prowadziła w ten sposób do fatalnych skutków, ponieważ Galicja ciąży ku Polsce, podczas gdy Czesi żądają niezależnego państwa, przy czym Węgry życzą sobie przerwania związków z Austrią i zgadzają się tylko na unię personalną, natomiat Słowianie południowi marzą o własnym dużym państwie, tak więc Niemcom nie pozostaje nic innego, jak szukanie ratunku w przyłączeniu (Anszlussie) do Niemiec, przy czym tego procesu rozkładu już nie można zatrzymać. Nikt dziś nie chce przelewać swojej krwi w obronie monarchii habsburskiej, której zagraża „słowianizacja”. Dlatego też jest rzeczą konieczną udzielenie pomocy austriackim Niemcom, na przykład przyłączając ich do Niemiec, nawet gdyby miałoby to oznaczać zmianę polityki wobec Czechów i Węgrów, z czym związane jest przyciągnięcie do Niemiec niezależnego pod względem ekonomicznym, a później być może także pod względem politycznym, Królestwa Czeskiego i Węgierskiego. Anszluss niemieckiej Austrii do Niemiec, pomimo wielu trudności, byłby stale jeszcze najlepszym rozwiązaniem ${ }^{36}$.

$\mathrm{Z}$ takim postawieniem sprawy we wspomnianym manifeście cesarza od razu chętnie utożsamiali się niemieccy nacjonaliści w monarchii habsburskiej. Niemieccy posłowie Rady Rzeszy z całej Przedlitawii utworzyli 21 października 1918 w Wiedniu własne Tymczasowe Zgromadzenie Narodowe, które ogłosiło nowe państwo - Republikę Niemieckiej Austrii, mające obejmować wszystkie terytoria zasiedlone przez Niemców, łącznie z regionami przygranicznymi krajów czeskich. Jednocześnie zagrozili, że sprzeciwią się

${ }_{35}$ Sborník dokumentů $k$ vnitřnimu vývoji v českých zemích za 1. světové války 1914-1918, Svazek V. Rok 1918, Praha 1997, s. 332-333.

${ }^{36}$ Aarthur C. Kogan, Genesis of the Anschluss Problem: Germany and the Germans of the Habsburg Monarchy in the Autumn of 1918, Journal of Central European Affairs, XX, 1960, No. 1, s. 32-34. 
ewentualnemu oderwaniu tych obszarów i obiecywali, że dostęp do Morza Adriatyckiego zapewnią sobie umową z innymi narodami. Jednocześnie nie wykluczano możliwości przyłączenia („Anszlussu”) w przyszłości Republiki Niemieckiej Austrii do Niemiec ${ }^{37}$. Ambasador Niemiec Botho von Wedel 21 października 1918 bezzwłocznie przekazał informację z Wiednia do Berlina, że manifest cesarza wywołał w monarchii naddunajskiej znikome wrażenie, ale zwolnił austriackich Niemców z obowiązku lojalności wobec Korony i legalizował rewolucję, w czym pozostałe narody miały przewagę przed Niemcami, którzy właśnie obwieścili powstanie Republiki Niemieckiej Austrii. Jej elementem składowym mają być także przygraniczne rejony Czech, jednak Czesi robią wszystko, aby je za pomocą daleko idących obietnic utrzymać. Część niemieckiego przemysłu oraz niemiecko-żydowskiego kapitału i szlachty niemieckiej także popiera utworzenie Republiki Niemieckiej Austrii, ponieważ mają ogromne obawy, że zostaliby sami z Czechami bez kontaktu z pozostałymi Niemcami. Zarazem wierzą w pomoc Węgrów. Jeśli jednak Czesi będą sprytni i zrezygnują z węgierskiej Słowacji, to wtedy Niemcy stracą także tego sprzymierzeńca. W razie gdyby Czechom udało się stworzyć jednolite państwo, stałoby się ono dla Niemców niewygodnym sąsiadem. Kiedy jednak im się to nie powiedzie, będą musieli zrezygnować z terenów przygranicznych i staną się zależni od Niemiec, które z Czechami jako z ,pragmatycznymi handlowcami” z łatwością dojdą do porozumienia i z czasem z pewnością uda się również pokonać nienawiść narodową. Czesi poprzez wschodnią część Śląska austriackiego kierują wzrok także na Polaków, którzy jednak nie darzą Czechów zbytnią sympatią, więc raczej im nie będą pomagać. Dlatego też Niemcy muszą zdecydowanie wspierać Niemców w Czechach, aby zapewnili sobie niezależność od Czechów i uzyskali na konferencji pokojowej nieograniczone prawo do samostanowienia. Niemcy muszą także zaopatrywać austriackich Niemców w artykuły spożywcze, w innym przypadku zostaną wydani na pastwę Czechów i Węgrów, a przecież nie mogą dopuścić do tego, aby austriaccy Niemcy zaginęli ${ }^{38}$.

Jednocześnie w samych Niemczech aktywizowali się zwolennicy opanowania Europy Środkowej przez rasę niemiecką. Arbeitsauschuß für Mitteleuropa (Komitet Roboczy dla Europy Środkowej), na czele ze słynnym propagatorem niemieckiej hegemonii w Europie Środkowej, Friedrichem Naumannem, przesłał 28 października 1918 do kanclerza Rzeszy Maksa Badeńskiego pilne memorandum, że dalekosiężne znaczenie dla wyników negocjacji pokojowych będzie mieć zachowanie niemieckiego wpływu na Polskę. Zarazem ustalenie wschodniej granicy Polski jest żywotnie ważne dla ochrony narodu niemieckiego przed wschodnim bolszewizmem. Z tego powodu państwo polskie musi pod względem politycznym, gospodarczym i kulturalnym pozostać nieodłącznym elementem Rzeszy Niemieckiej - przede wszystkim Górny Śląsk i Prusy Zachodnie z Gdańskiem. W tym celu należy koniecznie przekonać odpowiedzialnych przedstawicieli Polaków, że wycofanie się Niemców z Polski będzie mieć straszliwe skutki: 1) Wszyscy dotychczas wrogo ustosunkowani wobec Niemców przedstawiciele rozmaitych prądów politycznych w narodzie polskim, wywodzący się zwłaszcza z warstw mieszczańskich, zostaną zabici przez bolszewików i pozbawieni majątku. 2) Polskich nacjonalistycznych krzykaczy

${ }^{37}$ Außenpolitische Dokumente der Republik Österreich (1918-1938), Band 1, Selbstbestimmung der Republik. 21. Oktober 1918 bis 14 März 1919, Wien 1993, s. 69-73.

38 Německý imperialismus proti ČSR (1918-1939), Praha 1962, s. 44-43. 
wewnątrz Rzeszy Niemieckiej należy zmusić do całkowitego milczenia pod groźbą bolszewizacji Polski, aby sami zwrócili się do Wilsona z prośbą o zachowanie Polski jako części Rzeszy Niemieckiej. 3) Wilson ani Ententa nie są zainteresowani tym, aby ocalony dotychczas przed bolszewicka rewolucją kraj wydać na pastwę bolszewikom i dlatego nie będą popierać przyłączenia polskich prowincji Niemiec do Polski. Oprócz tego opuszczenie terenów nadbałtyckich i Polski będzie stanowić zagrożenie dla Ukrainy. Przy tym propozycja Ententy dotycząca złożenia broni przez Austro-Węgry zmierza przeciwko polityce Berlina do przyłączenia Austrii do Niemiec i usamodzielnienia się Węgier, które jednocześnie chcą zapobiec oderwaniu się swych narodów peryferyjnych. Dotychczasowa polityka Węgrów wobec Chorwatów i Słowaków nie była najszczęśliwsza, i dlatego też Ententa uznała prawa narodów Austro-Węgier, które już nie mogą przeciwdziałać oderwaniu się Słowaków, Słowian południowych, Rusinów (Ukraińców) i Rumunów, czyli utracie Słowacji, Dalmacji, Bośni, Hercegowiny, Chorwacji, Slawonii i Siedmiogrodu. Również Węgry staną się małym oskrzydlonym państwem, które ostatecznie za obietnicę zachowania swojej integralności może przejść na stronę Ententy i włączyć się do wojny przeciwko Niemcom. Oczekuje się, że lada dzień Turcja skapituluje i cała Europa Południowa przy pomocy Ententy przystąpi do wojny z Niemcami, przeciwko którym kolejny front stworzą Czesi, Słowacy i Polacy. Jednocześnie giną wszelkie nadzieje na utrzymanie Ukrainy i Rumunii, dlatego też należy skoncentrować dążenia przynajmniej na zachowaniu Polski w ramach Rzeszy Niemieckiej jako zapory przeciwko bolszewizmowi. Starania o utrzymanie hegemonii niemieckiej nad Europą Środkową, w połączeniu z podkreślaniem konieczności obrony przed „niebezpieczeństwem bolszewizmu” ze Wschodu, w okresie powojennym stało się jednym z ważnych narzędzi polityki zagranicznej, a potem odnowienia mocarstwowych ambicji Niemiec ${ }^{39}$. Ich elementem składowym było także świadome dążenie do pierwotnego wielkoniemieckiego rozwiązania przyszłości Europy Środkowej, oczywiście dostosowane do ówczesnej sytuacji ideologicznej i mocarstwowej w związku z rozpętaniem drugiej wojny światowej.

\section{Peter Prokš}

\section{"Mitteleuropa - Zwischeneuropa". German Concepts of Central Europe during the 'Great War' from 1914-1918}

\section{Summary}

In the 19th century, the period of dynamic development in Central Europe, several nations stood out due to their nationalism which became the most important principle of political, cultural and social life. At the same time, Germany's attempts to gain total control of the region were particularly apparent. According to contemporary views, prevailing among the supporters of the 'Greater German' solution for the future of Central Europe, the fight for the "imperial position of the uniform German Reich in the world" meant, primarily, a campaign against the Slavs. This was due to the fact that the Slavs represented the majority among the nations which were a part of the Habsburg monarchy, whose closer links with Germany were an indispensable condition for survival.

${ }^{39}$ Leon Gros feld, Polityka państw centralnych wobec sprawy polskiej w latach pierwszej wojny światowej, Warszawa 1962, s. 375-380. 
However, the ruling circles in Berlin increasingly raised doubts as to whether keeping alive the decaying Habsburg monarchy is reasonable. A question was asked whether it would be a better solution to rather incorporate Cisleithania, including the Czech countries, directly into Germany. The breakthrough in the development of Central Europe was the First World War. Germany also justified the unleashing of the war as a necessity for the survival of Austro-Hungary. The main opponent of German plans for the governance over Central and Eastern Europe was Russia. Therefore, following the defeat of the Russian army on the Eastern Front in May 1915 and moving of the troops of the Central Powers towards the East with the subsequent occupation of the Russian annexed part of the original Kingdom of Poland, also known as Congress Poland, the future of Poland and, at the same time, of the Habsburg Monarchy, along with the prospects of potential reconstruction of the AustroHungarian monarchy into a trialistic state, became a burning issue. In addition to the external pressure, Vienna also felt the internal pressure from supporters of close ties between the Habsburg Monarchy and Germany. In its quest for a total subjugation of Central Europe, Berlin attracted supporters with crystallized views in the very Austro-Hungary, primarily, among Greater German nationalists in Cisleithania who fully identified themselves with imperialistic plans of the German Empire. At the same time, they also hoped to push through their own imperialistic claims in the Habsburg Monarchy, by introducing an unconditional German hegemony in Cisleithania. However, the defeat of the German army on the Western Front in August 1918 forced Berlin to strongly reevaluate its initial, somewhat excessive, imperialistic ambitions. Although Germany's former imperialistic aspirations were irretrievably lost, Berlin was not going to accept the fact that the war (although lost) would not bring any benefit. Therefore, it focused its attention on its neighbour and ally, and considered the 'Anschluss', i.e. the acquisition of certain parts of the crumbling Habsburg monarchy. To this end, it intended to use, in particular, the Greater German tendencies in Cisleithania. The efforts to maintain the German hegemony over Central Europe, and stressing the need of protection against 'the danger of Bolshevism' from the East in the post-war period became some of the most important tools of foreign policy, and, subsequently, led to the renewal of Germany's imperial ambitions. They also included conscious striving for the original Greater German solution for the future of Central Europe, although adapted to the contemporary ideological situation of the empire, due to the unleashing of World War II.

Key words: Mitteleuropa, foreign policy of Germany, German conception of Central Europe, Friedrich Naumann 